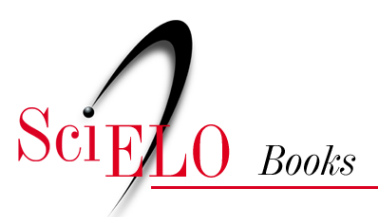

\title{
10 Tribo Tarchonantheae Kostel
}

\author{
Gustavo Heiden \\ João de Deus Medeiros
}

HEIDEN, G., and MEDEIROS, J.D. Tribo Tarchonantheae Kostel. In: ROQUE, N. TELES, A.M., and NAKAJIMA, J.N., comp. A família Asteraceae no Brasil: classificação e diversidade [online]. Salvador: EDUFBA, 2017, pp. 81-83. ISBN: 978-85-232-1999-4. https://doi.org/10.7476/9788523219994.0012.

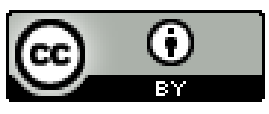

All the contents of this work, except where otherwise noted, is licensed under a Creative Commons Attribution 4.0 International license.

Todo o conteúdo deste trabalho, exceto quando houver ressalva, é publicado sob a licença Creative Commons Atribição $\underline{4.0}$. 


\title{
TRIBO TARCHONANTHEAE KOSTEL.
}

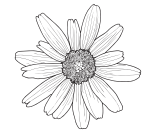 \\ Gustavo Heiden \\ João de Deus Medeiros
}

Tarchonantheae foi proposta por Kosteletzky (1833), compreendendo os gêneros Tarchonanthus L. e Brachylaena R. Br. A aceitação da tribo não foi imediata e o posicionamento desses gêneros em outras tribos, como Multisieae (BREMER, 1994) e Cardueae (HANSEN, 1991), variou ao longo da história. O monofiletismo de Tarchonantheae foi corroborado por estudos moleculares (KEELEY; JANSEN, 1991, KIM; LOOCKERMAN; JANSEN, 2002, FUNK et al., 2005), que reconheceram o seu posicionamento em Carduoideae.

Tarchonantheae compreende apenas os gêneros Tarchonanthus, com 2 (BEENTJE, 1999) ou 6 espécies (HERMAN, 2002), e Brachylaena com 11 espécies (BEENTJE, 2000). A tribo pode ser caracterizada pelas plantas dioicas, capítulos discoides ou disciformes, flores actinomorfas, unissexuais, anteras caudadas, calcaradas (Figura 4J), ramos do estilete curtos, agudos a obtusos, glabros, pápus cerdoso em 1-2 séries ou ausente. Todos os representantes da tribo são nativos da África e Península Arábica (ORTIZ, 2009), com uma espécie introduzida no Brasil (BFG, 2015).

\section{Descrição}

Arbustos ou árvores, dioicos, sem látex; folhas alternas. Capitulescência paniculiforme; receptáculo epaleáceo, alveolado, glabro ou piloso. Capítulos discoides ou disciformes, unissexuais, raramente com algumas 
flores bissexuais; invólucro campanulado a obcônico, brácteas involucrais imbricadas, margens hialinas. Flores com corola amarelada ou esbranquiçada; flores masculinas com corola actinomorfa, profundamente 5-lobada; estames com apêndice apical da antera deltado, anteras calcaradas e caudadas, pistilódio reduzido; flores femininas com corola actinomorfa 3-5-lobada, tubular a filiforme, estames reduzidos ou ausentes, estilete com ramos curtos e recurvados, agudos a obtusos no ápice, glabros. Cipselas cilíndricas a elipsoides, costadas, setulífera, carpopódio anuliforme; pápus ausente ou 1-2-seriado, barbelado.

Brachylaena discolor DC. (Figura 6A) é a única espécie da tribo ocorrente no Brasil. Nativa da África do Sul, Botsuana, Moçambique, Suazilândia e Zimbábue (BEENTJE, 2000), foi introduzida no país em meados de 1960 para a estabilização de dunas na praia do Moçambique, Parque Estadual do Rio Vermelho, na ilha de Santa Catarina, em Florianópolis, onde naturalizou-se, expandindo sua distribuição até a praia do Campeche, cerca de 30 quilômetros em direção ao sul da ilha, onde permanece restrita.

\section{Literatura recomendada}

BEENTJE, H. J. The genus Tarchonanthus (Compositae-Mutisieae), Kew Bulletin, London, v. 54, n. 1, p. 81-95, 1999.

BEENTJE, H. J. The genus Brachylaena (Compositae-Mutisieae). Kew Bulletin, London, v. 55, n. 1, p. 1-41, 2000.

BRAZIL FLORA GROUP - BFG. Growing knowledge: an overview of seed plant diversity in Brazil. Rodriguésia, Rio de Janeiro, v. 66, n. 4, p. 10851113, 2015.

BREMER, K. Asteraceae: cladistics and classification. Portland: Timber Press, 1994.

FUNK, V.A. et al.. Everywhere but Antarctica: using a supertree to understand the diversity and distribution of the Compositae. Biologiske Skrifter, Copenhagen, v. 55 p. 343-373, 2005. 
HANSEN, H. V. SEM-studies and general comments on pollen in tribe Mutisieae (Compositae) sensu Cabrera. Nordic Journal of Botany, Copenhagen, v.10, p. 607-623, 1991.

HERMAN, P. P. J. Revision of the Tarchonanthus camphoratus complex (Compositae, Tarchonantheae) in southern Africa. Bothalia, Pretoria, v. 32, n. 1, p. 21-28, 2002.

KEELEY, S. C.; JANSEN, R. K. Evidence from chloroplast DNA for the recognition of a new tribe, the Tarchonantheae, and the tribal placement of Pluchea (Asteraceae). Systematic Botany, Kent, v. 16, n. 1, p. 173-181, 1991. KIM, H.-G.; LOOCKERMAN, D. J.; JANSEN, R. K. Systematic implications of $n d h F$ sequence variation in the Mutisieae (Asteraceae). Systematic Botany, Kent, v. 27, n. 3, p. 598-609, 2002.

KOSTELETZKY, V. F. Allgemeine medizinisch-pharmazeutische Flora. Prague: Borrosch \& Andre, 1833. v. 2

ORTIZ, S. Tarchonantheae (Carduoideae). In: FUNK, V. A. et al. (Ed.). Systematics, Evolution and Biogeography of Compositae. Vienna: IAPT, 2009. p. 279-285. 